\title{
A Study of Raw Material Management Innovation Problems in Biomass Power Plants
}

\author{
Charcrit Sritong, Annop Kunavongkrit, and Chotihirun Piumsombun
}

\begin{abstract}
Study examines the raw material management innovation problems of biomass power plants in Thailand. In this study, the bamboo is the raw material being highlighted. In fact, the bamboo has never been utilized in Thailand as raw material for generating electricity of biomass power plant. Moreover, this study will analyze the problems in order to provide solutions to the problems related to the use of bamboo as raw material. The qualitative method was employed in this study. Furthermore, the in-depth interview technique was used for collecting data. The sample in this study comprised two main groups. The first group is the farmers who planted the bamboo, and the second group is the entrepreneurs who established the biomass power plant. The finding indicated that the main problem of farmers who planted the bamboo was the small number of bamboo produced. Generally, the bamboo in Thailand is used in various fields, so the amount of bamboo for producing electricity was not enough. The problems of entrepreneurs who established the biomass power plant were threefold. First, the return on investment in selling electricity to the Provincial Electricity Authority, Thailand (PEA), was low. Second, the transportation cost of raw material as agriculture residues was high. Third, the biomass power plant was not accepted by the community around the plant which was a major problem. As a result, the approaches to solving these problems are that the biomass power plants should set up cooperation between the farmers and the community around the power plant and give the chance to them to participate in the activities of the power plant as the biomass power plant community. Moreover, the community can produce the bamboo in conjunction with farming and sell the bamboo to the biomass power plant. These approaches can increase revenue to the community and reduce those problems.
\end{abstract}

Index Terms-Bamboo, biomass, innovation, power plant, raw material.

\section{INTRODUCTION}

Thailand has the potential to develop its natural resources as renewable energy. The current and important renewable form of energy is "biomass" which is derived from agricultural waste materials [1], [2]. As Thailand is an agricultural country, the agricultural wastes have various types which can be used as energy, especially in generating electricity. According to a report from the Thai Ministry of Energy, the biomass energy in Thailand has the potential to produce up to 4,600 Megawatts (MW). Then, the 15-year Renewable Energy Development Plan, 2008-2022 [3], [4],

Manuscript received May 20, 2012; revised July 4, 2012.

C. Sritong is with Graduate School, Chulalongkorn University, Bangkok, Thailand (email: charcrit_sritong@hotmail.com).

A. Kunavongkrit is with The office of the Commission on Agricultural Resource Education, Chulalongkorn University Bangkok, Thailand . has been launched with the goal of generating an initial electricity amount of $3,700 \mathrm{MW}$ by the year 2022 , representing a major increase from the current total installed capacity of 1,610 MW

However, the potential of biomass is scattered in and around the agricultural areas, so that it has the restrictions on the collection. Moreover, the transportation and storage cost of biomass are high. In addition, agriculturists have not recognized the need to utilize the agriculture waste due to the low adder rate, which is the cost of selling agriculture wastes. As a result, the current management system of raw materials for biomass power plant in Thailand is not very efficient.

Therefore, the objective of this study is to investigate the current problems in managing bamboo as raw material for generating electricity in biomass power plants in Thailand

\section{LITERATURE REVIEW}

P. Shanmughavel and K. Francis [5] had researched the growth of bamboos that were utilized as raw material in generating electricity for over six years. The results found that in the fifth month, the height of bamboo had increased by about $30 \mathrm{~cm}$ (without rain), as shown in Table I.

\begin{tabular}{lcccccc}
\multicolumn{6}{l}{ TABLE I: THE CHARACTERISTICS OF BAMBOO IN INDIA OVER 6 YEARS } \\
\hline \hline $\begin{array}{l}\text { Characteristics } \\
\text { of Bamboo }\end{array}$ & 1 & 2 & 3 & 4 & 5 & 6 \\
\hline $\begin{array}{l}\text { Amount of } \\
\text { bamboo } \\
\text { (per 0.4 Acre) }\end{array}$ & 1250 & 2250 & 3000 & 3500 & 4000 & 4250 \\
$\begin{array}{l}\text { Diameter breast } \\
\text { height (DHB) } \\
\text { (cm) }\end{array}$ & 2.3 & 3.3 & 4.3 & 4.8 & 6.3 & 8.3 \\
$\begin{array}{l}\text { Average Height } \\
\text { (m) }\end{array}$ & 1.44 & 3.26 & 9.6 & 21.8 & 27.2 & 28.5 \\
\hline \hline
\end{tabular}

Source: Adapted from P. Shanmughavel and K. Francis [5]

A. Arunachalam and K. Arunachalam [6] found that the heating value of bamboo was $16 \mathrm{MJ} / \mathrm{kg}$, while a $13 \%$ relative humidity at a constant value of carbon and sulphur content in fuel is not traceable. Therefore, it can be concluded that sulphur was not a problem. From the experiment, it showed that bamboo was a good fuel for generating energy when compared with other plants. The ash and volatile contents of tested bamboo were about $5 \%$ and $30 \%$, respectively, which was less than other woody biomass materials

\section{Methodology}

The qualitative method was employed in this research. The in-depth interview technique was used in collecting data. The samples were specified using the Snowball technique. Therefore, the samples of this study were categorized into 
two groups: five agriculturists who planted the bamboo, and five entrepreneurs who established the biomass power plants.

\section{RESEARCH RESULTS}

\section{A. The Problems in the Two Sample Groups}

From the in-depth interview of two sample groups, the results found the following.

Group 1: The agriculturists who planted the bamboo

The results found that the types of bamboo that agriculturists prefer to plant were the sweet bamboo (Dendrocalamus asper) and the Kim Sung bamboo (Bambusa beecheyana) [7]. Generally, the bamboo will propagate by means of bamboo shoot. The spread of bamboo shoot is about three to five per year. If the planted bamboo is without fertilizer, the bamboo culm can be cut for sale in the fourth year. Each culm is about 18 to 20 meters high, and weighs 60 to $80 \mathrm{~kg}$. In the case where fertilizer is provided, bamboo will grow faster, eventually yielding about 100 to 200 trees/tons/year with a weight of $600 \mathrm{~kg} / \mathrm{clump}$. The agriculturists planted 100 bamboo clumps/0.4 Acres, and they can achieve a maximum yield of five to six tons/year of bamboo shoots and 50 to 60 tons/year.

The cost of planting bamboo comprises the cost of preparation of the area for planting bamboo which was about 3500-5000 Baht/0.4 acre, and the feeding cost which was no more than $20 \%$ of selling cost. Furthermore, the bamboo can provide many benefits because all parts of it can be used and sold over its life time. The revenue from bamboo can be identified as follows:

1) The revenue from selling bamboo shoots.

2) The revenue from selling the culms of bamboo.

3) The revenue from selling branch seeds.

4) The revenue from selling the surface soil in the planted bamboo area, where the bamboo husk and leaves decompose as fertilizer.

The revenue can be concluded from the forecasting of yield and investment per 0.4 Acre by using household labors. For the first three years, the bamboo culms cannot be sold, so the revenue may be gained from selling bamboo shoots. In the fourth year until about the thirtieth year, revenue can be gained from selling bamboo culms and other parts

From Table II, the results showed that the break-even point was in year 2 because Kim Sung bamboo is a fast-growing species and gives a fast yield. The yield may be more than this study's results; it depends on the weather, soil conditions and other relevant factors of each area. Moreover, the results illustrated that the profit in year 2 was more than the first year; the income was about ten times as high for agriculturists who have limited spaces.

Therefore, the current problems of the bamboo-planting agriculturists can be described as follows:

1) The bamboo growing areas in Thailand do not produce enough so that bamboo must be imported from abroad in large amounts.

2) The agriculturists prefer to grow the plant following the short-term market demand, and the plant-growing system has not been made clear, so that some plants are in demand while others lack any such demand.
3) The areas, which are used for growing bamboo, are not prevalent in all areas of the country.

4) Most agriculturists have not recognized the benefits of growing bamboo; hence, growing bamboo is now not popular in Thailand.

5) In some areas in Thailand, there are still bamboo forests, so that the agriculturists can directly utilize the bamboo instead of growing it by themselves.

6) The government sector lacks a clear supportive policy for growing bamboo.

TABLE II: REVENUE AND EXPENSE FROM GROWING BAMBOO IN A PERIOD

\begin{tabular}{|c|c|c|}
\hline \multicolumn{3}{|c|}{$\begin{array}{l}\text { THREE YEARS } \\
\text { Description }\end{array}$} \\
\hline $\begin{array}{l}\text { planting } \\
\text { bamboo }\end{array}$ & Revenue & Expense \\
\hline Year 1 & $\begin{array}{l}\text { If the yield from selling } \\
\text { the bamboo shoot is } \\
500 \mathrm{~kg} \text {, and the price is } \\
10 \mathrm{Baht} \text { per } \mathrm{kg} \text {, then } \\
\text { the revenue equals } \\
5,000 \mathrm{Baht} / 0.4 \text { Acre. }\end{array}$ & $\begin{array}{l}\text { - Propagating } 100 \text { branches } \\
\text { per } 0.4 \text { Acre is about } 18,000 \\
\text { Baht per } 0.4 \text { Acre } \\
\text { - The feeding water system is } \\
\text { about } 5,000 \text { Baht per } 0.4 \text { Acre. } \\
\text { - The cost of one hundred } \\
\text { kilogram of fertilizer is } 1,200 \\
\text { Baht. } \\
\text { - The pesticide cost is } 500 \\
\text { Baht per } 0.4 \text { Acre. } \\
\text { Total expense is } 24,700 \text { Baht } \\
\text { per } 0.4 \text { Acre. }\end{array}$ \\
\hline Year 2 & $\begin{array}{l}\text { If the yield from selling } \\
\text { the bamboo shoot is } \\
5,000 \mathrm{~kg} \text {, and the price } \\
\text { is } 10 \mathrm{Baht} \text { per } \mathrm{kg} \text {, then } \\
\text { the revenue equals } \\
50,000 \mathrm{Baht} / 0.4 \text { Acre. }\end{array}$ & $\begin{array}{l}\text { If the cost of } 600 \mathrm{~kg} \text { of } \\
\text { fertilizer is } 1,200 \text { Baht. } \\
\text { Total expense is } 7,200 \\
\text { Baht } / 0.4 \text { Acre. }\end{array}$ \\
\hline Year 3 & $\begin{array}{l}\text { If the yield from selling } \\
\text { the bamboo shoot is } \\
6,000 \mathrm{~kg} \text {, and the price } \\
\text { is } 10 \mathrm{Baht} \text { per } \mathrm{kg} \text {, } \\
\text { Then, the revenue } \\
\text { equals to } 60,000 \\
\text { Baht } / 0.4 \text { Acre. }\end{array}$ & $\begin{array}{l}\text { If the cost of } 600 \mathrm{~kg} \text { of } \\
\text { fertilizer is } 1,200 \mathrm{Baht} \text {, the } \\
\text { Total expense is } 7,200 \\
\text { Baht } / 0.4 \text { Acre. }\end{array}$ \\
\hline Total & $\begin{array}{l}105,000 \mathrm{Baht} / 0.4 \text { Acre/ } \\
3 \text { years }\end{array}$ & 39,100 Baht/ 0.4 Acre/ 3 years \\
\hline
\end{tabular}

\section{Group 2: The biomass power plants}

Biomass power plant 1: This power plant has a capacity of $150 \mathrm{KW}$ for generating electricity using Gasification technology. The main raw material is the corn cobs. Other raw materials are the agricultural wastes such as the bar of grass and potato rhizomes. The amount of raw material, which is used in production, is about $224 \mathrm{Kg} / \mathrm{hr}$ [8]. The sources of raw materials include $50 \%$ from the agricultural waste collecting center, $40 \%$ from growing by themselves within the power plant space, and $10 \%$ from purchases made directly from agriculturists.

Biomass power plant 2: This power plant has a capacity of $500 \mathrm{KW}$ for generating electricity using Gasification technology. The main raw materials are 60 percent from pieces of fast growing woods and 40 percent from corn cobs. The amount of raw material, which is used in production, is about 5,389 tons/year [9]. The sources of raw materials include pieces of fast growing woods which can directly be purchased from agriculturists, and the corn cobs can directly be purchased from agriculturists or grow by themselves within the power plant space.

Biomass power plant 3: This power plant has a capacity of 9.9 MW for generating electricity using Steam Turbine 
technology. The main raw material is the chaff. The amount of chaff in production is about 240-300 tons/day [10]. The sources of raw material are purchased from subsidiaries and rice mills.

Therefore, the main problems in managing raw materials of biomass power plants can be described as follows:

1) The main problem of biomass power plant is acceptance by communities around the power plants, for it can cause problems in all aspects of the operation of power plant.

2) The raw material costs, which are used to generate electricity, have increased every year, about 20-30\% per year. The return on the sale of electricity to EPA is not adjusted according to the raw material's costs.

3) The areas for planting of fast growing trees such as eucalyptus trees as raw materials need a lot of space and take a long time from planting until harvest, about three to five years.

4) The yields per tree from fast growing trees are less, if compared with others.

5) The technology problem in generating electricity must not pollute the communities.

6) The transportation problems of raw materials can cause pollution during transportation, and can also influence the budget.

The problems in the two sample groups are summarized as shown in Fig. 1.

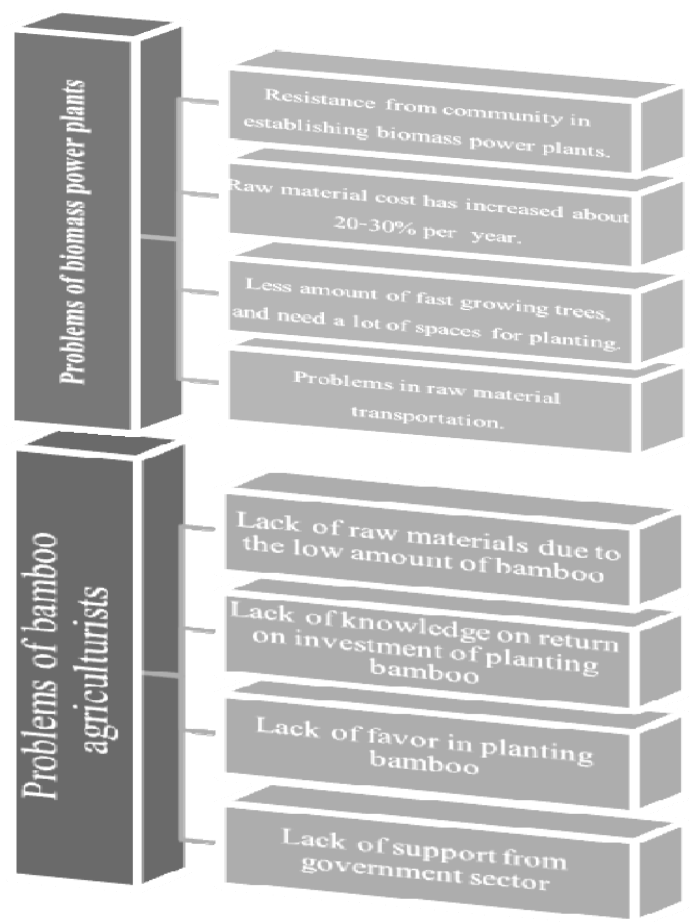

Fig.1. Summary of problems in the two sample groups.

\section{B. The approaches of problem-solving}

From the aforementioned problems of the two sample groups (agriculturists and biomass power plants), the approaches to solving those problems are as follows:

1) Establish public hearings for public comments and participation in projects of power plants.

2) Provide the agricultural information around communities, so that communities can manage their lands for growing the bamboo and take part in generating electricity of power plants.

3) Provide knowledge on the benefits of growing bamboo which can become their income supplement.

4) Establish contract farming, which is the insurance of the bamboo price and purchasing quantity. This will benefit both the buyer who can control the raw material cost and quantity, and the agriculturists who can meet market demand and raw material cost.

5) Specify the quantity or proportion between growing bamboo by themselves and purchasing them from communities.

6) Evaluate the satisfaction level of agriculturists who participated in the growing bamboo projects.

\section{ACKNOWLEDGMENT}

I would like to express my sincere gratitude to the agriculturists and biomass power plants who kindly provided the information and opinions without which this study could not have been completed. Include a note with your final paper indicating that you request color printing.

\section{REFERENCES}

[1] Data of bamboo in Thailand. [Online]. Available: http://rdi.ku.ac.th/kasetresearch/54GroupEconomic/-18Maliwan_Hat/t emplate.html

[2] Data of green technology, green word foundation in Thailand. [Online]. Available: http://www.greenworld.or.th

[3] Ministry of energy in Thailand, Development plan of renewable energy 15 year (2008 - 2022), Depaartment of energy and energy conservation, Department of energy in Thailand.

[4] Plan of energy conservation 20 year (2011 - 2030), Department of energy in Thailand.

[5] P. Shanmughavel and K. Francis, "Above ground biomass production and nutrient distribution in growing," India, Biomass and Bioenergy, vol. 10 , no. S/6, pp. 383-391,1996

[6] A. Arunachalam and K. Arunachalam, "Evaluation of bamboos in eco-restoration of 'jhum' fallows in Arunachal Pradesh, ground vegetation, soil and microbial biomass," Forest Ecology and Management, vol.159, pp 231-239, 2002.

[7] Development plan of alternative energy and fuel consumption of the country in Thailand. [Online]. Available: http://www.energychoices.in.th/node/297

[8] S. Songsak and W. Aree, "Overview of contract farming in Thailand Lessons learned," ADB institute discussion paper no, vol. 112, 2008.

[9] X. Zeng, Y Ma, and L. Ma, "Utilization of straw in biomass energy in China," China, Renewable and Sustainable Energy Reviews, vol. 11, pp. 976-987, 2007.

[10] Z. ZhaohuaBamboo, "Industry's Impact evaluation on rural sustainable development in Anji, China," in proc. INBAR. (2005) international Training Workshop on Small Daily Processing Technologies and Machines, 2005, pp. 16-33.

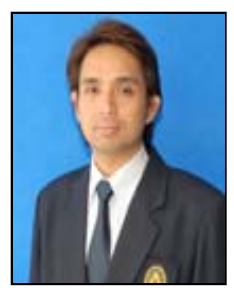

Charcrit Sritong currently is a $\mathrm{Ph} . \mathrm{D}$ candidate in Technopreneurship and Innovation Management Program of Graduate School, Chulalongkorn University in Thailand . I has a B.Sc. degree (Industrial Physics and Medical Instrumentation) from King Mongkut's Institute of Technology North Bangkok in Thailand, and MBA degree (Manufacturing Management) from Mahanakorn University of Technology in Thailand 


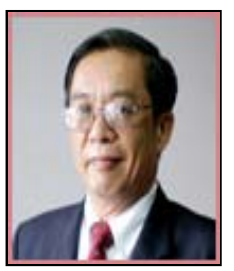

Professor Dr.Annop Kunavongkrit Ph.D. He currently is a Director of The Office the Commission on Agricultural Resource Education (OCARE) at Chulalongkorn University in Thailand

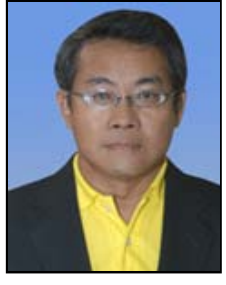

Chotihirun Piumsombun has a B.Sc. degree Science for Biology from Chulalongkorn University in Thailand an Master degee for Master of Administration from Vancouver,British Columbia University in Canada. He currently is a President of Police Major General Chuan-Ms.Proytip Piumsombun Foundation ( Family-owned Charity Foundation for Prachinburi Province Education development) 